\title{
THE PRICE OF FANATICISM: THE CASUALTIES OF THE BULHOEK MASSACRE
}

\section{D.H. MAKOBE \\ DOCUMENTATION SERVICE DIRECTORATE, SANDF}

The Bulhoek massacre is a well-known event in popular memory of many black South Africans and a standard feature in accounts of South African history. Despite this fact historians have not yet established the exact number of Israelites who were killed as a result of their attack on the Police on 24 May 1921. It is the purpose of this article to establish a reliable number of Israelites who were killed during the Bulhoek massacre.

The Union Defence medical personnel that accompanied the Police force to Bulhoek consisted of Major M. Welsh (in charge), Sergeant Major W. Richardson, Sergeant S. Allan, Sergeant Wallace, Private Kriel and Driver Valentine with one motor ambulance and field equipment. En route from Pretoria to Queenstown, the team was joined by Private Sutton from Tempe hospital in Bloemfontein. ${ }^{1}$

On their arrival at Queenstown the medical personnel accompanied Colonel Truter to an interview with the senior Magistrate of Queenstown E.C.A. Welsh. The latter stressed the seriousness of the situation and warned that the Police would not be able to carry out the Government's instructions without bloodshed. The medical personnel became convinced that bloodshed was unavoidable. They decided to ascertain the exact number of available accommodation at the Frontier Hospital in Queenstown. They found that only about 25 Europeans and up to 40 Africans could be accommodated. ${ }^{2}$ After checking available accommodation at Frontier Hospital, they erected a tent hospital at the show grounds of Queenstown.

On 24 May 1921 the medical team moved out of Potgieters kraal farm with the force on the way to Bulhoek to carry out the Government's instructions at Bulhoek. ${ }^{3}$ Following the fight, the medical personnel awaited orders from Colonel Truter. After the Israelites' attack on the Police, Colonel Truter informed Lieutenant Colonel Woon to wait on his flank until he saw the Police of the first regiment occupying the Israelite settlement. While still waiting on his flank, three Israelites came from their settlement with a flag of truce. They asked for permission to assist their wounded comrades lying on the battlefield. Lieutenant Colonel Woon told them that they could send as many parties as they liked, provided they came out with white flags. ${ }^{4}$

After Major Harvey had disarmed and searched the Israelites found at the settlement, Lieutenant Colonel Woon together with the medical personnel was instructed to advance to the Israelites' location. On arrival the medical personnel was instructed to establish a dressing station in front of Enoch's house to treat wounded Israelites. ${ }^{5}$ A party of Police and prisoners, under Sergeant Major Bench was ordered by Colonel Truter to collect the dead and wounded. On 25 May a total of 163 killed Israelites were collected. They were all buried in one large grave. Before the Police could close the grave the Israelites were allowed to hold a burial service. During the night of 24 May 1921, the Police were so tired that they could not continue collecting wounded Israelites from the bushes. Colbrun Mgijima, a relative of Enoch and a teacher by profession, organised a band of Israelite women to take on the work to succour the wounded and bring them in for attention. Many of the Israelites were so badly wounded that there was no chance of recovery for them. Many of the badly wounded were collected in the vicinity of Maxims Kopje. It seems the machine gun fire in particular that was located at the Kopje was responsible for the severe wounds of the Israelites. A total of 37 Israelites died during the night of 25 May 1921 due to severe gun wounds at the dressing station. ${ }^{6}$

Dr John Cranke, the District Surgeon of Queens-

SAP Archives: Box 4202, File 61850|21 \K, Native Affairs Commission Report, Medical Report on the expedition to Bulhoek with the South African Police by Major M. Welsh - Commissioner of Police, Pretoria, 24 June 1921.

Ibid.

See part one.

SAP Archives: Box 4202, File 6|850|21|J, Commissioner's Report, Report by Lieutenant Colonel Woon, 24 May 1921.

SAP Archives: Box 4202, File 61850|21/K, Native Affairs Commission Report, Medical report on the expedition to Bulhoek with the South African Police by Major M. Welsh - Commissioner of Police, Pretoria, 24 May 1921.

6 SAP Archives: Box 4202, File 6 $850|21| \mathrm{K}$, Native Affairs Commission Report; Medical report on the expedition to Bulhoek with the SAP by Major M. Welsh- Commissioner of Police, Pretoria, 24 June 1921. 




Wynberg Military Hospital

SANDF Archives, $861-893$

town, was instructed by the Commissioner of Police to make the necessary arrangements to accommodate the wounded Israelites at the Frontier Hospital in Queenstown. Due to the limited number of beds in the Hospital, Dr Cranke hired 16 Tarpaulins from the South African Railways and Harbours to be used as additional accommodation. ${ }^{7} \mathrm{He}$ also arranged with the local doctors to help treat wounded Israelites. The District Surgeon furthermore requested the Automobile Club of Queenstown to help transport the wounded Israelites from the dressing station at Enoch's house to the Frontier Hospital. ${ }^{8}$

A total of 157 wounded Israelites were treated at the dressing station; 37 of the wounded died while undergoing treatment at the station and five more died when they were taken to the Frontier Hospital. Seventeen Israelites died later while undergoing treatment at the Frontier Hospital, and it was arranged that they would be buried by the prison authorities. $^{9}$

It was estimated by the Police, though the number is by no means correct due to the lack of records from the side of the Israelites, that approximately 500 armed Israelites (both men and boys) took part in the battle with the Police. A considerable number of them escaped, one being a man with a bullet wound in the shoulder who was found as far away as Lady Frere. Some Israelites with gun wounds were arrested in the various blocks of Kamastone location. ${ }^{10}$ There were incidents that further shows that Israelites who were not badly wounded attempted all the available avenues to escape. Two of the Israelites attempted to escape by wearing women's clothes, but did not succeed. One of the two who was caught in this undignified position was Innes Mgijima, one of Enoch's sons. He had endeavoured to make his disguise even more complete than the others, for, in addition to wearing female attire, he carried a baby. ${ }^{11}$

The transfer of the wounded to the Frontier Hospital caused many problems. Apart from the lack of beds, there was not enough staff to take care of the wounded Israelites, and members of the Police and temporary African workers were used to help the wounded Israelites. Meanwhile the Department of Native Affairs was making arrangements with the Department of Native Labour in Johannesburg to send 15 African orderlies to the hospital. ${ }^{12}$

Owing to the insufficient facilities at the Frontier Hospital, the seriously wounded Israelites were transferred to the Wynberg Military Hospital and the Roberts Heights Military Hospital in Pretoria. Major Nicol, together with nursing sister Barker, staff nurse Phillips and five African orderlies accompanied the 41 wounded Israelites from Queenstown to Wynberg Military Hospital. ${ }^{13}$ The remaining ten

SAP Archives: Box 4202, File 6|850|21 10 , Financial Correspondence, Letter from the General Manager of the South African Railways and Harbours - Chief Supply Officer, South African Police, Pretoria, 8 November 1921.



9 CAD: Treasury Records (hereafter TES), TES, File 34|123, Expenditure in connection with the rising of the Israelites at Bulhoek, Letter Secretary for Finance - Native Affairs Secretary, 10 February 1922.

10 ELM: Bulhoek tragedy, pp. 28-29.

11 ELM: Bulhoek tragedy, p. 29.

12 SAP Archives: Box 4202, File 6|850\21|N, Medical Matters; Telegram Director of Native Labour, Johannesburg - Magistrate Queenstown and Native Department Pretoria, 30 May 1921.

13 SAP Archives: Box 4202, File 6|850|21\A; Israelites at Bulhoek. Report by Major W.P. Nicol - Director of Medical Services, Pretoria, retransport of wounded Israelites Queenstown to Wynberg, 12 June 1921. 


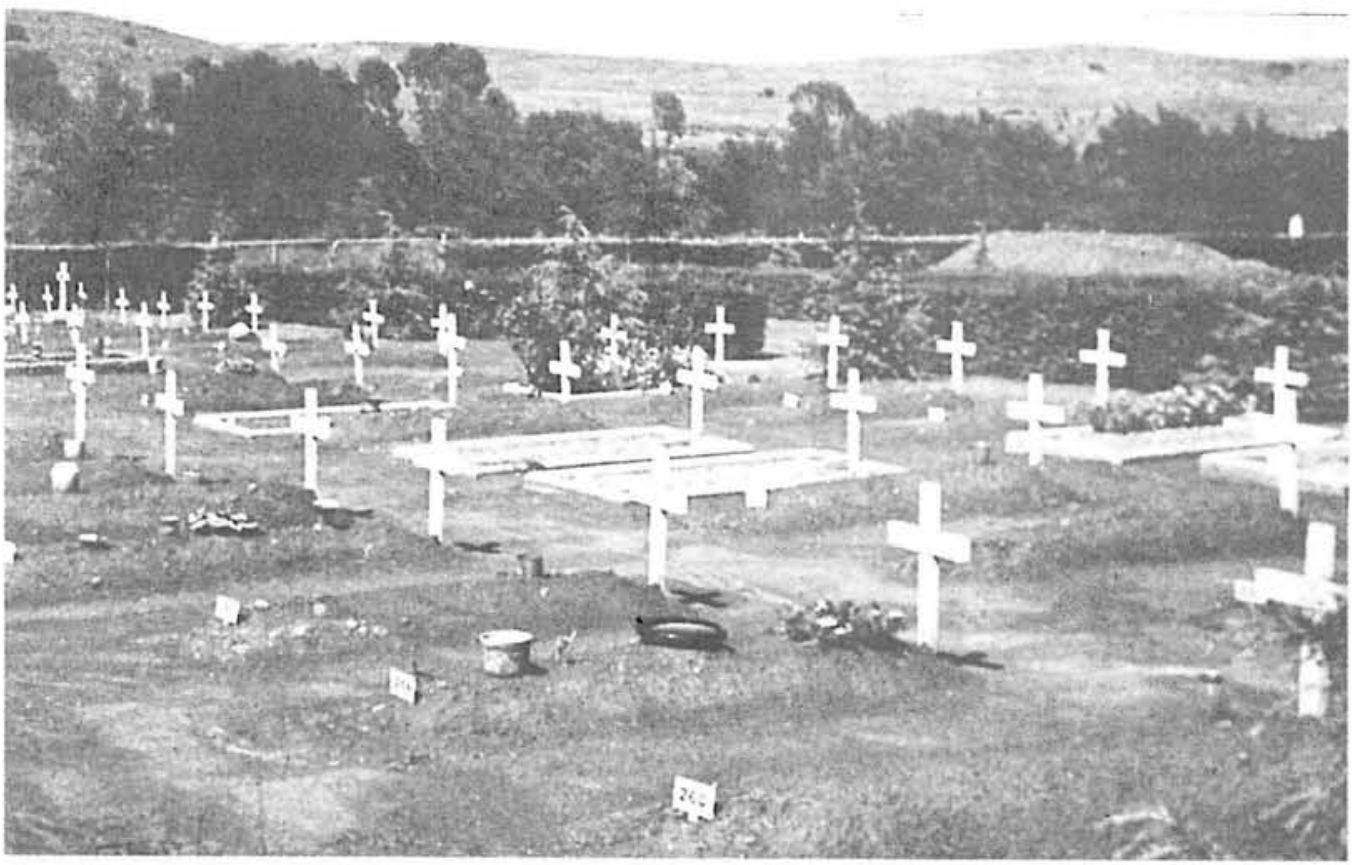

Military Cemetery, Roberts Heights (now Voortrekkerhoogte)

SANDF Archives, 71-63286

African Orderlies joined the 59 wounded Israelites at Roberts Heights Military Hospital. ${ }^{14}$

Three of the wounded Israelites died at the two military hospitals while undergoing treatment. The first to die at Roberts Heights Military Hospital was Kelly Jaantje, who died on 25 June 1921. The cause of his death was pneumonia and a gunshot wound on the left thigh. His interment took place on 26 June 1921 at the Military Cemetery, Roberts Heights. ${ }^{15}$

The second Israelite, Moses Ntsodo, died on 7 September 1921, at Roberts Heights, the cause of his death being gunshot wounds in the chest and right knee and septicaemia. ${ }^{16}$ The third Israelite, Ogali Nyeli died on 22 October 1921 at Wynberg Military Hospital. ${ }^{17}$

After undergoing treatment at the two military hospitals, the rest of the Israelites were sent back to Queenstown to stand trial. This commenced in Queenstown on 21 November 1921 and lasted until 2 December 1921.

\section{Conclusion}

The exact number of Israelites who were killed at Bulhoek is still a contested issue. Historians such as P. Maylam, E. Roux and W.K. Hancock put the number of killed Israelites at $163 .{ }^{18}$ This was the number of Israelites who were buried on the 25 May 1921. Not one of the three historians have done an intensive study of the Bulhoek massarce. They have only referred to the massacre in passing. The much celebrated Readers Digest Illustrated History of South Africa, the Real Story put the figure at 183. ${ }^{19}$ It is difficult to establish the source of reference for this figure.

In an interview with the Daily Dispatch before the 70th commemorative anniversary of the Bulhoek massacre in 1991, the Secretary General of the Church of God and Saints of Christ, Elder Moses Mzimkulu, said that the commemoration would be a religious event and would "clear up historical distortions" of the massacre. ${ }^{20}$ Mzimkulu stated that the figures contained in history books were part of what he termed historical distortions of the massa-

14 SAP Archives: Box 4202, File 6\850\21, Miscellaneous, Roll of Native Orderlies specifically employed with Israelites at Roberts Heights Military Hospital.

15 SAP Archives: Box 4202, File 6|850|21, Misceilaneous. Letter, Director of Medical Services, Pretoria - The Commissioner of Police, re: Native Kelly Jaantje (Israelite), 1 July 1921.

16 SAP Archives: Box 4202, File 6\850|21, Miscellaneous. Letter, Office of the Deputy Commissioner South African Police - The Secretary South African Police, re Death of Native Moses Ntsodo at Roberts Heights on 7 September 1921, 12 September 1921.

17 SAP Archives: Box 4202, File 61850|21, Miscellaneous, Letter, Deputy Commissioner South African Police, Cape Town - The Secretary South African Police, Pretoria, 22 October 1921.

18 See: P. Maylam, A History of the African People of South Africa, p.161; E. Roux, Time Longer than rope, p.137 and W.K. Hancock, Smuts: the fields of peace, p.89.

19 Readers Digest illustrated History of South Africa, the real story, Expanded second edition, p.326.

20 ELM: A. Trench, "Israelite gathering aims to right historical distortions", Daily Dispatch, 13 December 1991. 
cre. He stated that his congregation believed that as many as 360 Israelites lost their lives during the fight on 24 May 1921. ${ }^{21}$ Rubin Nxopo, who was 16 years old in 1921 and 87 years in 1992 stated that he could not remember the exact number of Israelites who died at Bulhoek but argued that hundreds of them died. ${ }^{22}$

The difficulty of establishing the exact figure is complicated by the fact that it is not known how many Israelites took part in the attack although the number is estimated at 500 . Furthermore there is no evidence of the number of Israelites who were at Bulhoek before the fight. The number is estimated at 3000 . The Israelites were unable to establish the number of missing comrades as they came from different places. ${ }^{23}$

From research conducted it can be argued that a total of 225 Israelites died during the fight with the Police. A total of 163 killed Israelites were buried at Bulhoek on the 25 May 1921, 37 died while undergoing treatment at the dressing station established in front of Enoch's house, five died on the way to Frontier Hospital from the dressing station, 17 died at Frontier Hospital, two died at Roberts Heights Military Hospital while one died at Wynberg Military Hospital. It is possible that some Israelites with gunshot wounds might have died elsewhere trying to escape, thus making it impossible to ascertain the exact number. The figure of 225 might therefore not be correct but represents the number documented in Police records. Until further evidence comes to light it has to be accepted as the most reliable.

\section{BIBLIOGRAPHY}

\section{PRIMARY SOURCES}

\section{CENTRAL ARCHIVES DEPOT, PRETORIA}

Treasury records

File $34 \backslash 23$

\section{SOUTH AFRICAN POLICE ARCHIVES, PRETORIA}

Box 4202, Bulhoek Massacre records:

File $6 \backslash 850 \backslash 21 \backslash \mathrm{A}$, Israelites at Bulhoek.

File $6 \backslash 850 \backslash 21 \backslash \mathrm{H}$, Newspaper cuttings.

File 6\850\21\K, Native Affairs Commission Report

File 6 $650 \backslash 21 \backslash \mathrm{J}$, Commissioner's Report.

File $6 \backslash 850 \backslash 21 \backslash \mathrm{N}$, Medical matters.

File $6 \backslash 850 \backslash 21 \backslash 0$, Financial correspondence.

File 6\850|21, Miscellaneous.

\section{SECONDARY SOURCES}

\section{EAST LONDON MUSEUM, EAST LONDON}

Daily Dispatch, 13 December 1991.

Sunday Star, 26 June 1996.

The Bulhoek tragedy illustrated, the full story of the Israelite Settlement at Ntabelanga near Queenstown, Daily Dispatch, nd.

HANCOCK, W.K., Smuts: the fields of force, 1919 - 1950. vol 2, Cambridge, 1968.

MAYLAM, P., A History of the African people of South Africa: from the Early Iron Age to the 1970s. Cape Town, 1986.

Readers Digest illustrated History of South Africa, the real story. Expanded second edition Cape Town, 1988.

ROUX, E., Time longer than rope. Wisconsin, 1964. 